\title{
SYNTHESIS AND X-RAY STUDY OF AMMONIUM POLYVANADOMOLYBDATE XEROGELS
}

\author{
V. Bondarenka ${ }^{\text {a }}$, A. Pašiškevičius ${ }^{\text {a }}$, V.L. Volkov ${ }^{b}$, and G.S. Zakharova ${ }^{\text {b }}$ \\ ${ }^{a}$ Semiconductor Physics Institute, A. Goštauto 11, LT-01108 Vilnius, Lithuania \\ E-mail: bond@pfi.lt \\ ${ }^{\mathrm{b}}$ Institute of Solid State Chemistry, Pervomayskaya 91, 620219 Yekaterinburg, Russian Federation \\ E-mail: volkov@ihim.uran.ru
}

Received 1 December 2006

\begin{abstract}
$\left(\mathrm{NH}_{4}\right)_{2-x} \mathrm{H}_{x} \mathrm{~V}_{9} \mathrm{Mo}_{3} \mathrm{O}_{31 \pm \delta} \cdot n \mathrm{H}_{2} \mathrm{O}(x=0,1)$ gels were produced from $\mathrm{V}_{2} \mathrm{O}_{5}, \mathrm{NH}_{4} \mathrm{VO}_{3}, 40 \% \mathrm{H}_{2} \mathrm{O}_{2}$, and Mo powder by using sol-gel technology. Synthesized gels were investigated by X-ray photoelectron spectroscopy methods. The shape and position of the complex core photoelectron lines V $2 p$, O $1 s, \mathrm{C} 1 s$, Mo $3 p$, Mo $3 d$, and $\mathrm{N} 1 s$ were analysed for the gels with different $x$ values. The valences of the $\mathrm{V}$ and Mo ions, which have an important role in the electrical conductivity of the compounds, was studied. It has been found that the molybdenum is in the stable $\mathrm{Mo}^{6+}$ state. The vanadium ions are in $\mathrm{V}^{5+}$ and $\mathrm{V}^{4+}$ states. The reduction ratio of vanadium ions is about 0.043 independent of the $x$ value. The position of the $\mathrm{N} 1 s$ peak indicates that the nitrogen is connected with hydrogen in $\mathrm{NH}_{4}$ ions.
\end{abstract}

Keywords: vanadium oxides, hydrates, ammonium, XPS

PACS: $72.80 . \mathrm{Ga}, 81.20 . \mathrm{Fw}, 82.70 . \mathrm{Gg}, 82.80 . \mathrm{Pv}$

\section{Introduction}

Hydrated vanadium compounds $\mathrm{M}_{2} \mathrm{~V}_{12} \mathrm{O}_{31 \pm \delta}$ $\cdot n \mathrm{H}_{2} \mathrm{O}$, where $\mathrm{M}$ is an alkali-metal, possess a number of unusual properties, which make them the candidate materials for many technological applications $[1,2]$. When prepared by using sol-gel technology methods [3], they have a very labile structure, where $\mathrm{V}-\mathrm{O}$ chains are separated by water molecules, and the interlayer distance in such xerogels varies from 8.8 to $40 \AA$, depending on water content [4]. In addition to water molecules and $\mathbf{M}^{n+}$ cations, the polyvanadates readily intercalate organic solvents, $N$-alkyl ammonium organic ions, and metal complexes [5]. The sol-gel technology was also used to prepare $\mathrm{M}_{x} \mathrm{~V}_{12-y} \mathrm{Mo}_{y} \mathrm{O}_{31 \pm \delta} \cdot n \mathrm{H}_{2} \mathrm{O}$ xerogels [1]. Such compounds might incorporate $\mathrm{H}_{3} \mathrm{O}^{+}, \mathrm{NH}_{4}{ }^{+}$, hydroquinone, or polyvinyl alcohol in the gaps between $\mathrm{V}$ O-Mo layers [6-9].

The synthesis, structure, and some physical properties of ammonium polyvanadomolybdate xerogels are described in [8]. The aim of this work is the characterization of the states of various elements and chemical bounds between them in the V-O-Mo- $\mathrm{NH}_{4}$ system xerogels.

\section{Experimental}

As starting materials, we used $\mathrm{V}_{2} \mathrm{O}_{5}, \mathrm{NH}_{4} \mathrm{VO}_{3}, 40 \%$ $\mathrm{H}_{2} \mathrm{O}_{2}$, and Mo powder. $\mathrm{V}_{2} \mathrm{O}_{5}$ and Mo powders in a suitable proportion were dissolved in $\mathrm{H}_{2} \mathrm{O}_{2}$ to form mixed solutions of pervanadic (molybdic) acids. Slow heating up to $333 \mathrm{~K}$ initiates the decomposition of the peroxide compounds, followed by gelation. The reactions with the participation of $\mathrm{V}_{2} \mathrm{O}_{5}$ are

$$
\begin{aligned}
& \mathrm{V}_{2} \mathrm{O}_{5}+2 \mathrm{H}_{2} \mathrm{O}_{2}=2 \mathrm{HVO}_{2}\left(\mathrm{O}_{2}\right)+\mathrm{H}_{2} \mathrm{O}, \\
& \mathrm{HVO}_{2}\left(\mathrm{O}_{2}\right)+3 \mathrm{H}_{2} \mathrm{O}= \\
& \mathrm{VO}(\mathrm{OH})_{3}\left(\mathrm{OH}_{2}\right)_{2}+\frac{1}{2} \mathrm{O}_{2}, \\
& 2\left[\mathrm{VO}(\mathrm{OH})_{3}\left(\mathrm{OH}_{2}\right)_{2}\right] \rightarrow \mathrm{V}_{2} \mathrm{O}_{5} \cdot 5 \mathrm{H}_{2} \mathrm{O} .
\end{aligned}
$$

Scheme (3) represents polymerization of the neutral precursor, resulting in a hydrous $\mathrm{V}_{2} \mathrm{O}_{5}$ gel, which can be regarded as the polyvanadic acid $\mathrm{H}_{2} \mathrm{~V}_{12} \mathrm{O}_{31 \pm \delta}$ $\cdot n \mathrm{H}_{2} \mathrm{O}$.

Mo ions replace $\mathrm{V}^{5+}$ in the resulting compounds, $2 \mathrm{~V}^{5+} \rightarrow \mathrm{V}^{4+}+\mathrm{Mo}^{6+}$ or $2 \mathrm{~V}^{5+}+\mathrm{Mo}^{6+}+\mathrm{OH}^{-}$. The $\mathrm{V}^{4+}$ and $\mathrm{OH}^{-}$ions increase the degree of polymerization and stability of the gels. Decomposition of the 


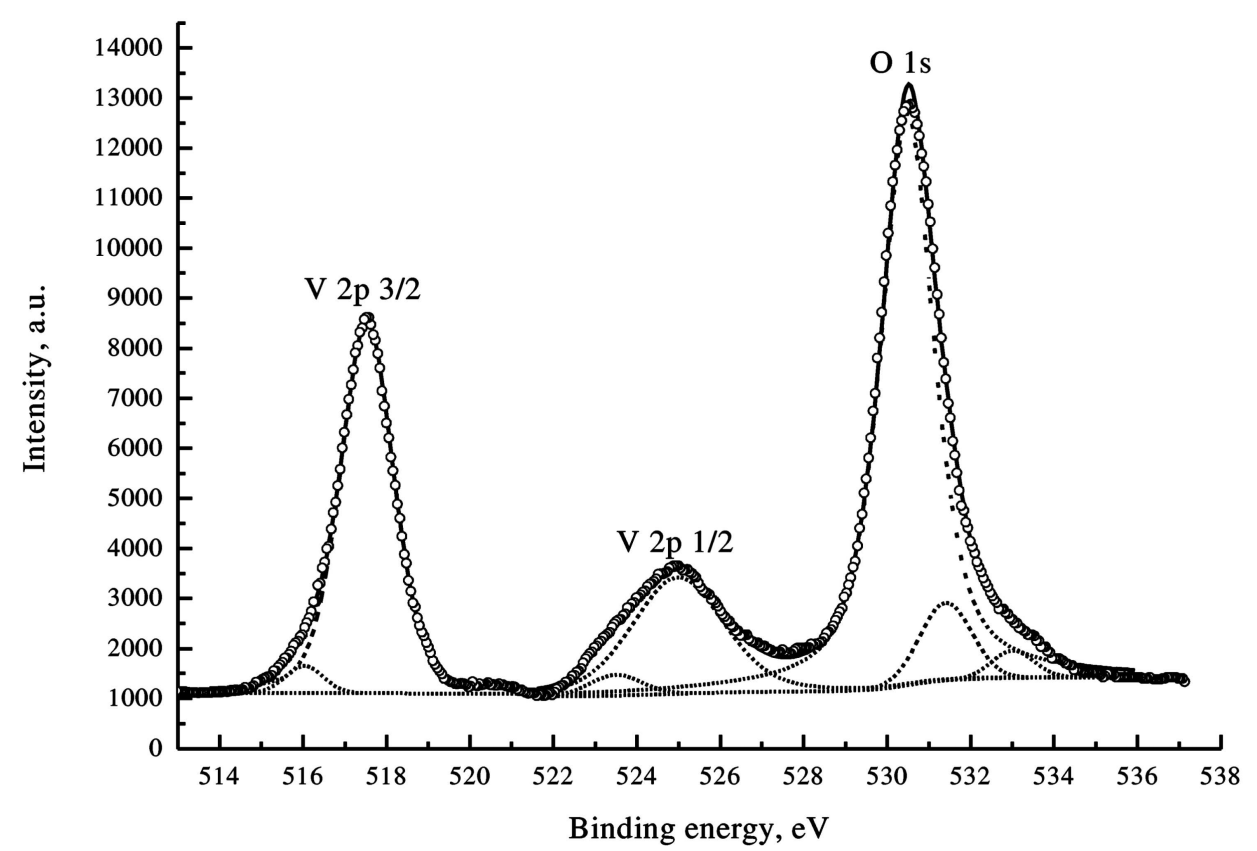

Fig. 1. XPS V-O region spectra of $\left(\mathrm{NH}_{4}\right) 2 \mathrm{~V}_{9} \mathrm{Mo}_{3} \mathrm{O}_{31 \pm \delta} \cdot n \mathrm{H}_{2} \mathrm{O}$ xerogel.

peroxide solution of vanadium containing $\mathrm{NH}_{4}{ }^{+}$is not accompanied by gelation, whereas, in the presence of molybdenum, $\left(\mathrm{NH}_{4}\right)_{2-x} \mathrm{H}_{x} \mathrm{~V}_{9} \mathrm{Mo}_{3} \mathrm{O}_{31 \pm \delta} \cdot n \mathrm{H}_{2} \mathrm{O}(x=$ $0,1)$ gels are formed. Obtained gels were deposited on $\mathrm{Ni}$ substrates by screen printing method and dried in air. The thickness of prepared films was about $10 \mu \mathrm{m}$. The films have layered structure where $\mathrm{NH}_{4}{ }^{+}$ions and $\mathrm{H}_{2} \mathrm{O}$ are incorporated between the V-O-Mo layers [10]. Such structure causes anisotropy of physical properties of the produced films along and across the V-O-Mo layers that is peculiar to the other hydrated vanadium compounds [11].

Surface chemical composition was controlled by using the X-ray photoelectron spectroscopy (XPS) method. XPS spectra were measured with a VG ESCALAB MK II spectrometer $\left(\mathrm{Mg} \mathrm{K}_{\alpha 1,2}\right.$ source, $1253.6 \mathrm{eV})$. The working pressue in the analytic chamber was maintained below $10^{-7} \mathrm{~Pa}$ during the spectrum analysis. Before the measurement the surface of samples was cleaned using $\mathrm{Ar}^{+}$ion bombardement at $3 \mathrm{kV}$ and current density of $10 \mu \mathrm{A} \cdot \mathrm{cm}^{-2}$ for $3 \mathrm{~min}$. The energy scale was calibrated using the $\mathrm{Au} 4 f_{7 / 2}$ peak $(84.0 \mathrm{eV})$. Charging effects were taken into account using the $\mathrm{C} 1 s$ peak $(284.6 \mathrm{eV})$.

\section{Results and discussion}

Figure 1 presents the XPS V-O region spectra of $\left(\mathrm{NH}_{4}\right) 2 \mathrm{~V}_{9} \mathrm{Mo}_{3} \mathrm{O}_{31 \pm \delta} \cdot n \mathrm{H}_{2} \mathrm{O}$ xerogel (points are experimental data). $\mathrm{V} 2 p$ and $\mathrm{O} 1 s$ peaks are composed of several components the parameters of which are
Table 1. $\mathrm{V}-\mathrm{O}$ region fitting parameters of $\left(\mathrm{NH}_{4}\right) 2 \mathrm{~V}_{9} \mathrm{Mo}_{3} \mathrm{O}_{31 \pm \delta} \cdot n \mathrm{H}_{2} \mathrm{O}$ xerogel.

\begin{tabular}{cccrr}
\hline Peak & $\begin{array}{c}\text { Binding } \\
\text { energy, eV }\end{array}$ & $\begin{array}{c}\text { FWHM, } \\
\mathrm{eV}\end{array}$ & $\begin{array}{r}\mathrm{RA}^{1}, \\
\%\end{array}$ & $\begin{array}{r}\mathrm{G} / \mathrm{L}^{2}, \\
\%\end{array}$ \\
\hline $\mathrm{V} 2 p_{3 / 2}\left(\mathrm{~V}^{4+}\right)$ & 516.03 & 1.50 & 1.27 & 70 \\
$\mathrm{~V} 2 p_{3 / 2}\left(\mathrm{~V}^{5+}\right)$ & 517.53 & 1.06 & 28.10 & 100 \\
$\mathrm{~V} 2 p_{1 / 2}\left(\mathrm{~V}^{4+}\right)$ & 523.50 & 1.45 & 1.36 & 100 \\
$\mathrm{~V} 2 p_{1 / 2}\left(\mathrm{~V}^{5+}\right)$ & 524.98 & 2.59 & 14.36 & 80 \\
$\mathrm{O} 1 s\left(\mathrm{O}^{2-}\right)$ & 530.48 & 1.53 & 49.06 & 40 \\
$\mathrm{O} 1 s(\mathrm{O}-\mathrm{C})$ & 531.40 & 1.46 & 4.71 & 100 \\
$\mathrm{O} 1 s\left(\mathrm{H}_{2} \mathrm{O}\right)$ & 533.01 & 1.18 & 1.14 & 100 \\
\hline
\end{tabular}

${ }^{1}$ relative area of the peak

${ }^{2}$ Gaussian and Lorentzian ratio

given in Table 1. V $2 p_{3 / 2}$ and $\mathrm{V} 2 p_{1 / 2}$ peaks consist of two components and $\mathrm{O} 1 \mathrm{~s}$ peak consists of three components. It is possible to subsume the $\mathrm{V} 2 p_{3 / 2}$ peak components with binding energies 516.03 and $517.53 \mathrm{eV}$ under the quadrivalent [12] and quinquivalent [13] vanadium ions in the xerogel. The same is possible to say about the $\mathrm{V} 2 p_{1 / 2}$ peak components with binding energies of 523.5 and $524.98 \mathrm{eV}$ [14]. Taking the $\mathrm{V} 2 p_{3 / 2}$ peak area data from Table 1 we may calculate the vanadium ion reduction ratio

$$
C=\frac{\mathrm{V}^{4+}}{\mathrm{V}^{5+}+\mathrm{V}^{4+}},
$$

where $\mathrm{V}^{5+}$ and $\mathrm{V}^{4+}$ are corresponding ion concentrations. In our case $C=0.043$, i. e. quadrivalent vanadium constitutes just $4.3 \%$ of vanadium ion content, similar as in other vanadium hydrates [10]. The reduc- 


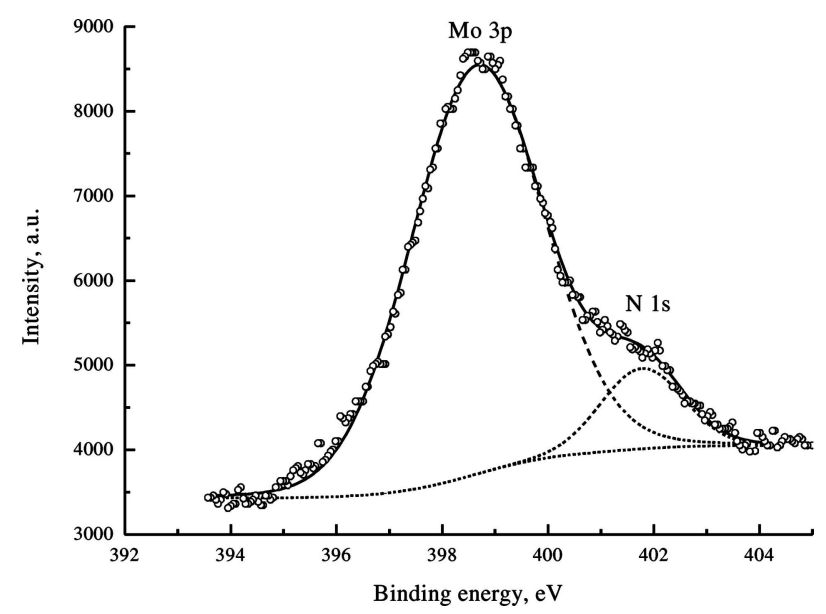

(a)

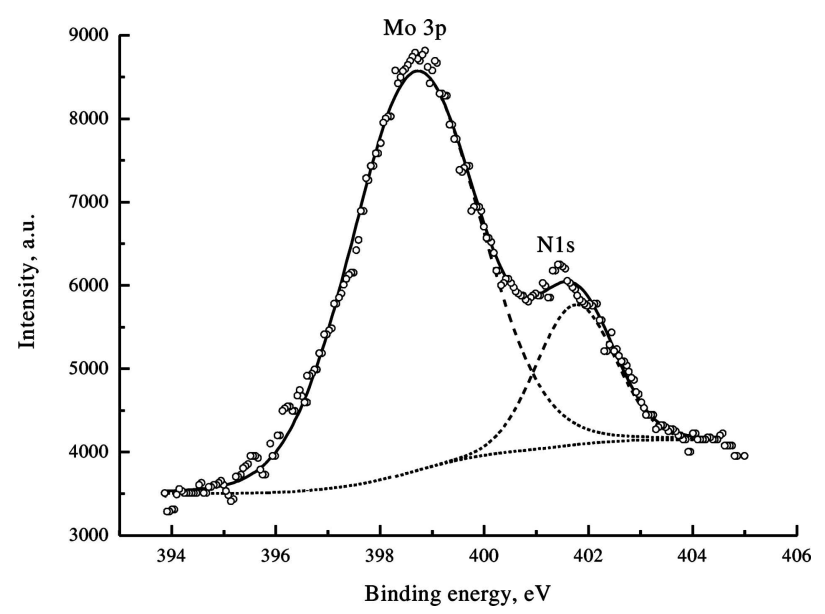

(b)

Fig. 2. XPS spectra of molybdenum (Mo $3 p$ ) and nitrogen region of $\left(\mathrm{NH}_{4}\right)_{2-x} \mathrm{H}_{x} \mathrm{~V}_{9} \mathrm{Mo}_{3} \mathrm{O}_{31 \pm \delta} \cdot n \mathrm{H}_{2} \mathrm{O}$ xerogels, (a) for $x=0$, (b) for $x=1$.

Table 2. Mo $3 p-\mathrm{N} 1 s$ region fitting parameters of $\left(\mathrm{NH}_{4}\right)_{2-x} \mathrm{H}_{x} \mathrm{~V}_{9} \mathrm{Mo}_{3} \mathrm{O}_{31 \pm \delta} \cdot n \mathrm{H}_{2} \mathrm{O}$ xerogels.

\begin{tabular}{lcccccccc}
\hline \multirow{2}{*}{ Peak } & \multicolumn{2}{c}{ Binding energy, eV } & \multicolumn{2}{c}{ FWHM, eV } & \multicolumn{2}{c}{$\mathrm{RA}^{1}, \%$} & \multicolumn{2}{c}{$\mathrm{G} / \mathrm{L}^{2}, \%$} \\
\cline { 2 - 9 } & $x=0$ & $x=1$ & $x=0$ & $x=1$ & $x=0$ & $x=1$ & $x=0$ & $x=1$ \\
\hline Mo $3 p_{3 / 2}$ & 398.68 & 398.65 & 2.9 & 2.95 & 87.78 & 94.03 & 44 & 57 \\
$\mathrm{~N} 1 s$ & 401.76 & 401.73 & 1.76 & 1.57 & 12.22 & 5.97 & 100 & 100 \\
\hline${ }^{1}$ relative area of the peak \\
${ }^{2}$ Gaussian and Lorentzian ratio
\end{tabular}

tion ratio of vanadium ions for $\left(\mathrm{NH}_{4}\right) \mathrm{HV}_{9} \mathrm{Mo}_{3} \mathrm{O}_{31 \pm \delta}$ $\cdot n \mathrm{H}_{2} \mathrm{O}$ gel also is about 0.043 .

The $\mathrm{O} 1 s$ peak has three components (Fig. 1 and Table 1). The first one, a more intensive peak with binding energy of $530.48 \mathrm{eV}$ matches the $\mathrm{O}_{2}$ - ions [15] linked with vanadium and molybdenum ions. The second one, less intensive $(531.4 \mathrm{eV})$, is possible to ascribe to the relations with carbon [15]. And the last and weakest component with binding energy at $533.01 \mathrm{eV}$ matches the oxygen linked with hydrogen in water molecules [16].

In Fig. 2 the XPS spectra of molybdenum (Mo $3 p$ ) and nitrogen region ((a) for $x=0$, (b) for $x=1$ ) is shown. The fact that Mo $3 p$ and $\mathrm{N} 1 s$ binding energies are close to each other makes the analysis of this spectrum more complex, whereas the neglect of nitrogen presence in the gel makes the interpretation of this spectrum quite difficult. The spectrum component parameters are given in Table 2. The component with binding energy $398.68 \mathrm{eV}$ matches $\mathrm{Mo}^{6+}$ ions [17] and the component with binding energy $401.76 \mathrm{eV}$ matches nitrogen which is in $\mathrm{NH}_{4}{ }^{+}$ions [18]. Mo $3 d$ emission comprises the pair of spin-orbit doublets with Mo $3 d_{3 / 2}$ and Mo $3 d_{5 / 2}$ binding energies of $\sim 236$ and $\sim 233 \mathrm{eV}$ respectively that was observed in other vanadium hydrates containing molybdenum [19].

\section{Conclusions}

The composition and chemical structure of $\left(\mathrm{NH}_{4}\right)_{2-x} \mathrm{H}_{x} \mathrm{~V}_{9} \mathrm{Mo}_{3} \mathrm{O}_{31 \pm \delta} \cdot n \mathrm{H}_{2} \mathrm{O}(x=0,1)$ gels synthesized by the sol-gel technology were determined by $\mathrm{X}$-ray photoelectron spectroscopy methods. The vanadium ions are in the $\mathrm{V}^{5+}$ and $\mathrm{V}^{4+}$ states with reduction ratio of about 0.043 independent on the $x$ value. The investigation of the Mo $3 p$ and Mo $3 d$ spectra shows that the molybdenum ions are in the stable $\mathrm{Mo}^{6+}$ states. The $\mathrm{O} 1 s$ peak consists of three components, where the first one is connected with vanadium and molybdenum ions, the second is possible to subsume under relations with carbon, and the third belongs to oxygen linked with hydrogen in water molecules. The position of the $\mathrm{N} 1 s$ peak indicates that the nitrogen is connected with hydrogen in $\mathrm{NH}_{4}$ ions.

\section{Acknowledgement}

This work was partly supported by the Lithuanian State Science and Studies Foundation, Grant No. V-30/2006 within the frame of COST D35. 


\section{References}

[1] V.L. Volkov, Intercalation Phases Based on Vanadium Oxides (Uralskii Nauchnyi Tsentr Akademii Nauk SSSR, Sverdlovsk, 1978) [in Russian].

[2] J. Livage, Vanadium pentoxide gels, Chem. Mater. 3(4), 578-593 (1991).

[3] D.R. Ulrich, Prospects of sol-gel processes, J. NonCryst. Solids 100(1-3), 174-193 (1988).

[4] P. Aldebert, H.W. Haesslin, N. Baffier, and J. Livage, Vanadium pentoxide gels: III. X-ray and neutron diffraction study of highly concentrated systems; onedimensional swelling, J. Colloid. Interface Sci. 98(2), 478-483 (1984).

[5] P. Aldebert, N. Baffier, J.-J. Legendre, and J. Livage, $\mathrm{V}_{2} \mathrm{O}_{5}$ gels: A versatile host structure for intercalation, Chim. Miner. 19(4-5), 485-495 (1982).

[6] R.M. Guseinov and V.D. Prisyazhnyi, Protonic solid electrolytes, Ukr. Khim. Zh. (Russ. Ed.) 58(10), 823833 (1992).

[7] A.B. Yaroslavtsev, Proton conductivity of inorganic hydrates, Usp. Khim. (Russ. Chem. Rev.) 63(5), 449455 (1994) [in Russian].

[8] V.L. Volkov, G.S. Zakharova, L.V. Kristallov, M.V. Kuznetsov, G. Dai, and M. Tong, Synthesis, structure, and properties of ammonium polyvanadomolybdate xerogels, Inorg. Mater. 37(4), 408-412 (2001).

[9] V.L. Volkov, G.S. Zakharova, M.V. Kuznetsov, A. Jin, Q. Zhu, and W. Chen, Nanocomposites of $\mathrm{V}_{1.67} \mathrm{M}_{0.33} \mathrm{O}_{5 \pm \delta} \cdot n \mathrm{H}_{2} \mathrm{O}(\mathrm{M}=\mathrm{Ti}$ or $\mathrm{Mo})$ xerogels intercalated with hydroquinone and poly(vinyl alcohol), Russ. J. Inorg. Chem. 51(9), 1339-1344 (2006).

[10] V.L. Volkov, G.S. Zakharova, and V. Bondarenka, Xerogels of Simple and Complicated Polyvanadates (Ural Branch of Russian Acad. Sci., Yekaterinburg, 2001) [in Russian].

[11] G.S. Zakharova, V.L. Volkov, V.V. Ivanovskaia, and A.L. Ivanovskii, Nanotubes and Similar Nanostruc- tures of Metal Oxides (Ural Branch of Russian Acad. Sci., Yekaterinburg, 2005) [in Russian].

[12] C.D. Wagner, J.F. Moulder, L.E. Davis, and W.M. Riggs, Handbook of X-ray Photoelectron Spectroscopy (Perkin-Elmer Corporation, Physical Electronics Division, 1995).

[13] B.F. Dzhurinskii, D. Gati, N.P. Sergushin, V.I. Nefedov, and Ya.V. Salyn, Simple and coordination compounds. An X-ray photoelectron spectroscopic study of certain oxides, Zh. Neorg. Khim. (Russ. J. Inorg. Chem.) 20, 2307-2314 (1975).

[14] G. Hopfengärtner, D. Borgmann, I. Rademcher, G. Wedler, E. Hums, and G.W. Spitznagel, XPS studies of oxidic model catalysts: Internal standards and oxidation numbers, J. Electron Spectrosc. Related Phenomena 63(2), 91-116 (1993).

[15] T.L. Barr, An ESCA study of termination of the passivation of elemental metals, J. Phys. Chem. 82(16), 1801-1810 (1978).

[16] C.-O.A. Olsson and S.E. Hornstrom, An AES and XPS study of the high alloy austenic stainless steel 254 SMO tested in a ferric chloride solution, Corrosion Sci. 36(1), 141-151 (1994).

[17] G.D. Khattak, M.A. Salim, A.S. Al-Harthi, D.J. Thompson, and L.E. Wenger, Structure of molybdenum-phosphate glasses by X-ray photoelectron spectroscopy (XPS), J. Non-Cryst. Solids 212(2-3), 180-191 (1997).

[18] C.R. Clayton and K.G. Martin, Evidence of anodic segregation of nitrogen in high nitrogen stainless steels and its influence on passivity, in: Proceedings of International Conference on High Nitrogen Steel HNS 88, Lille, May 1988, eds. A. Hendry and J. Foche (London, 1989) pp. 256-260.

[19] V. Bondarenko, S. Kaciulis, A. Plesanovas, V. Volkov, and G. Zacharova, Photoelectron spectroscopy of the poly-vanadium transition metal acids, Appl. Surf. Sci. 78(1), 107-112 (1994).

\title{
AMONIO POLIVANADATU-MOLIBDATU SINTEZE் IR RENTGENO FOTOELEKTRONINIU SPEKTRU TYRIMAS
}

\author{
V. Bondarenka ${ }^{\text {a }}$, A. Pašiškevičius ${ }^{\text {a }}$, V.L. Volkov ${ }^{b}$, G.S. Zakharova ${ }^{b}$ \\ ${ }^{a}$ Puslaidininkiu fizikos institutas, Vilnius, Lietuva \\ ${ }^{\mathrm{b}}$ Kietojo kūno chemijos institutas, Jekaterinburgas, Rusija
}

\section{Santrauka}

Iš $\mathrm{V}_{2} \mathrm{O}_{5}, \mathrm{NH}_{4} \mathrm{VO}_{3}, 40 \% \mathrm{H}_{2} \mathrm{O}_{2}$ ir Mo miltelių, naudojant zolių ir gelių technologiją, buvo pagaminti $\left(\mathrm{NH}_{4}\right)_{2-x} \mathrm{H}_{x} \mathrm{~V}_{9} \mathrm{Mo}_{3} \mathrm{O}_{31 \pm \delta}$. $n \mathrm{H}_{2} \mathrm{O}(x=0,1)$ geliai. Pateikti minètų gelių cheminès sudèties bei atskiru elementu būsenu tyrimo Rentgeno fotoelektroninès spektroskopijos (RFS) metodu rezultatai. Analizuoti V $2 p, \mathrm{O} 1 s, \mathrm{C} 1 s$,
Mo $3 p$, Mo $3 d$ ir N $1 s$ smailių parametrai bei vanadžio ir molibdeno jonu valentingumas. Nustatyta, kad molibdeno jonai yra stabilioje $\mathrm{Mo}^{6+}$ būsenoje, o vanadžio $-\mathrm{V}^{4+}$ ir $\mathrm{V}^{5+}$ būsenose. Vanadžio jonų redukcijos santykis nepriklauso nuo gelių sudetties ir yra apie 0,043 . N $1 s$ smailès ryšio energijos vertè rodo, kad azotas geliuose surištas su vandeniliu $\mathrm{NH}_{4}$ jonuose. 